\title{
The Internationalization Strategy Research on Hotel Enterprise Group Brand
}

\author{
Xu Junyi \\ YinXing Hospitality Management College of CUIT, Chengdu Sichuan 611743, China
}

Keywords: Hotel enterprise group; Internationalization; Strategy

\begin{abstract}
With the development of economy and the progress of the society, our country hotel enterprise also has had great progress. Hotel industry is the earliest open industry in our country, so compared with other industries; it has strong openness and international congenital advantage. Hotel enterprise's internationalization development is the development trend of hotel business under the background of economic globalization, and the environment at the same time provides opportunities for international hotel group development. Nowadays in the development of hotel internationalization, there are a lot of problems in our country's hotel industry need to be solved.
\end{abstract}

\section{INTRODUCTION}

In recent years, with the deepening of reform and opening up, China's economy develops continuously. Economic globalization is now the pattern of international development, and the connection between the countries all over the world is more and closer. As the holiday system reform and the improvement of people's standard of living, tourism is growing up and has obtained rapid development. Hotel industry is the industry which first contacts with international advanced level in the process of our reform and opening up. Although hotel industry in our country's reform and opening up has made great progress and development in mechanism and business philosophy, but compared with international advanced level, there is still a big gap. Compared with international hotels, hotels in China have the problems like small size, weak strength, and low taste. To speed up hotel enterprise group brand internationalization, the current problems in the development must be solved.

\section{THE PRESENT SITUATION ANALYSIS OF HOTEL MANAGEMENT}

\section{Strong international hotels and weak national hotels}

With the advancement of reform and opening up and economic globalization, China's hotel market main body is gradually diversified, and more and more foreign companies dominate the market. Because there's a big gap with international level and our national hotels, unavoidably strong international hotels and weak national hotels situation appears. China's local hotels are squeezed by the international hotels with narrow living space. Chinese hotel market is gradually dominated by foreign brands and foreigners, so western characteristics hotels share a lot in China's hotel industry. As the saying goes, only the national dominates the world. Our national hotel market contains little China's national characteristics, and Chinese elements do not fit in very well.

\section{Strong capital and weak professional personnel}

With reform and opening and the development of global economy, our country's openness is deepening gradually, and our country's economic level has had very big enhancement. This provides enough money for hotel industry development and capital ability is very strong. Many large hotels and upscale hotels are constructed unceasingly and are gradually put into operation. Compared to capital ability, hotel industry talents in our country are very weak. Professional talents are scarce, and management personnel are often incompetent and can't bore the burden of management. This brought great influence to the hotel's management and is not conducive to strengthen the management of the hotel and improve the competitiveness of the hotel.

\section{Strong turnover and weak profit}

Along with the development of tourism industry, hotel's turnover increases gradually, but this is 
just the surface. The actual profit is little, and many senior hotel revenue and profits are even lower than the budget hotel's revenue and profits. Although the hotel has a high turnover, it also expends lot of money, especially star hotels. Because of its low efficiency, there are too many employees. This leads to high cost. Without professional management, there is no high income and high returns.

\section{Strong imitation and weak innovation}

In any industry in China, due to low technical level and lack of professional high-quality talents, generally there are imitation rather than innovation, and the hotel industry is no exception. The business model and business philosophy are often copied the experience of others, which completely ignores the actual situation and actual needs of their own development, thus appeared same type business, clone training, etc., and sometimes even the service is copied. After long time development, China's hotels are the same and featureless. Naturally they have lost their competitiveness and are unable to compete with foreign international hotels.

\section{Strong interest and weak culture}

The development of market economy increases the competition between industries and enterprises in the industry, so they all make interest in the first place, and hotel industry is no exception. Hotel industry's main products are the service art supported by cultural force, but the hotel development attaches great importance to interests blindly, ignoring culture. It only pays attention to behavior, and plays down the importance of theory. The development values current interests and ignores the interests of long-term development. Short-term vision brings resistance to the development of the hotel, which misleads the development of the hotel.

\section{THE NECESSITY OF LOCAL HOTELS’ INTERNATIONAL OPERATION}

\section{The inevitable requirement of economic globalization}

With the advancement of economic globalization, China also keeps up with the development trend of the era, and joined the World Trade Organization. China's foreign economic development occupies the important position in the economy, and China's economic development not only opens the domestic demand and promotes the growth of external demand. In this open pattern, there is a big gap between China's service industry and that of developed countries. Economic globalization strengthens the connection between the countries all over the world, and international tourism also has made great progress and development. A large number of multinational hotels constantly expand in China market, and China's hotel industry internationalization is the trend of The Times under this trend, and is the inevitable path of development.

\section{Entry business tourists surge}

With the improvement of people's living standard, tourism has rapidly developed. International tourism also has great progress, and hotel development also gradually ushers in the spring. Consumers are the basis and driving force for hotel development, and only relying on continuous flow of consumers can consumption space be expanded broader so as to win more business opportunities. Because of our country's international hotel continuous occupancy, the internationalization of our hotels would have a big impact. The increase of inbound travel proposes challenges and opportunities for the internationalization of hotels.

\section{International high-end hotels rise}

The deepening of reform and opening up in China and the development of market economy make the main body diversified in hotel market, and more and more foreign hotels get into the market in our country, such as Marriott, Star-wood, Hilton international hotel. These international hotels meet the needs of international business people, and provide a variety of options for our country's government personnel. International hotel becomes the first choice for high-end consumers, and the local hotels are neglected. Some economic hotels can have a little hope of survival with low price. This shows that internationalized development of China's hotels is inevitable. 


\section{HOTELS’ INTERNATIONAL STRATEGY}

\section{Correct choice of hotel target market}

Our country people's living standards are improving and more and more people go abroad to travel, but a lot of Chinese tourists are not accustomed to the eat and live in destination because of a lot of difficulties in language, habits or customs. The hotels' internationalization development in our country can start this. Hotel enterprises with overseas visitors' mature experience are strongly encouraged to select corresponding countries or regions as the first step toward hotel internationalization in our country based on domestic crowd overseas tourism and implement transnational operation. The internationalized development of China's hotel can provide better local service for China's overseas tourism tourists in order to attract more customers and reduce operational risk. The initial stage of China's hotel industry internationalization can choose Malaysia and Mexico and other countries, or in terms of geographical and cultural advantages, choose Hong Kong, Macao and Taiwan and ASEAN countries. Piled up a certain intellectual capital in our country, China's hotel industry may get to a higher stage from the preliminary stage and gradually get into European and American markets.

Hotel industry brand internationalization needs market positioning, and market positioning is based largely on China's overseas tourists and overseas Chinese, and some western developed countries citizens with low income and curious about Chinese culture. In terms of products, it is mainly foods. Chinese tourists' eating habits are very important, so in the process of hotel internationalization, take care of Chinese tourists' eating habits, and blend some western elements on the basis of this to make visitors feel national characteristic and the smell of home.

\section{Strengthen group operation}

The development of international well-known hotels is given priority to merger and acquisition activities in cross-border, regional and industry and brand. Our country's independent hotels and low group level hotel management do not have the competitive advantage. So in this respect, China's hotel industry should learn from the experience of international famous hotel development, strengthen the integration of resources between hotels, speed up the attack and expansion of world's travel market thus further improve their international competitiveness. Collectivization development is the inevitable requirement of China's hotel industry internationalization development, and at this point, Jinjiang Hotel group in China is very successful. It actively complies with the international trend of hotel development on the basis of our country's basic national condition, enhances the development of integration and plays the advantages of their collectivization. It stands out in our country's hotel industry and has made positive exploration for the development of hotel industry in China.

\section{The reasonable planning and capital operation}

To speed up the process of hotel industry internationalization, the most effective means is reasonable planning and capital operation. For state-owned hotels in China, although there is a strong capital backing, the management of state-owned hotels is mixed with government's management. In order to speed up its internationalization, government functions must be truly separated from enterprise management with clear responsibilities. Develop state-owned hotels with modern enterprise system and build the operating system. The internationalization of our country hotel should always base on the actual situation of their own development and draw lessons from the successful experience of international hotels. Integrate the hotels' tangible and intangible capital, and flexibly use various means of capital operation in international capital markets to make hotel group's resources get more optimal allocation. Use a small amount of resources to control hotel capital so as to promote the hotel brand internationalization of our country.

\section{Develop international hotel personnel training strategies}

To effectively promote China's hotel brand internationalization, it is necessary to cultivate professional high-quality talents. Practice has proved that competition between international hotels is actually talent competition. The hotel industry development capital ability in our country is stronger but talent strength is very weak. Since the reform and opening in China, universities have 
set up hotel related majors, but talent cultivation mode and the quality and quantity still can't meet the needs of the development of our country international hotel. China hotels need a large number of high quality international management personnel to go abroad. In the face of such demand, hotels must make the corresponding international hotel personnel training strategy, increase the contact and cooperation with universities to provide enough international management talents for hotel internationalization development. Provide personnel support and intellectual support for the internationalization development of hotel. And hotel enterprises should combine their own development needs and present situation and make reasonable training plan and system to ensure staff's training. Provide substantial training content and make the staff improve their professional quality and professional level in training constantly. The hotel can also employ some successful experiences foreign talents for hotel management so as to improve the level of hotel internationalization.

\section{Establish multi-brand structure adapting to different levels}

In the international market competition of hotel industry, brand is the intangible asset of a hotel. It is crucial for the hotel and it has a direct relationship with the competitiveness of the hotel and also concerns the ability of sustainable development of the hotel. Hotels can only enhance the level of internationalization through diversified development. In the face of China's hotel industry, it can be found that they are mostly single, so there is a loss of customers. This is very bad for the development process of internationalization. International hotel's management cost of the hotel is very high, so it lacks competitive advantage in customers. But this provides the opportunity for our countries' hotel internationalization development. In the face of such situation, when making multi-brand strategy in our country, give full consideration to China's tourism and low-end business model customer demand, establish chain brand giving priority to low star hotels to attack the weak link of international hotel market. Operate according to regulations after building brand. Do a good job in brand positioning, and blend with Chinese characteristics in each brand. As China's international hotel chains, outline our country's characteristics for example in aspects such as construction and catering and build China's international hotel brand with Chinese characteristics.

\section{CONCLUSION}

The development of economic globalization, inbound travel surge and rising of international high-end hotels, etc., put forward the necessary requirement for China's international hotel development. There are many problems in hotel operation and development for a long time in our country, and the invasion of foreign international hotels compresses hotel's survival and development in China. In the face of such situation, we must correctly choose hotel goal market, strengthen group operation, reasonable plan capital operation, set up international hotel personnel training strategy, and establish different levels of multi-brand structure. Then the internationalization level of China's hotel industry brand can be effectively improved.

\section{REFERENCES}

[1] He Xiaorong, Luo Wenbin. Franchise or management contract: hotel international expansion strategy choice [J]. Journal of Travel, 2012, 12:54-59.

[2] Wang Ling. The exploration of China's domestic hotel internationalization [J]. Productivity Research, 2014, 11:118-122.

[3] Zhang Qing, Zhang Xiang. Retrospect and prospect of hotel enterprise internationalization research [J]. Journal of World Geography Research, 2015 01:143-151.

[4] Chen Xing. The speeding up of domestic hotel management internationalization [J]. Modern Hotel, 2009 01:50 to 52.

[5] Han Xiushen, Zhang Jian. China hotel industry "go out" and refer to the international experience---- take French Accor group for example [J]. Journal of International Economic Cooperation, 2011, 12:56-59. 